\title{
Bacteriological examination of Computer keyboards and mouse devices and their susceptibility patterns to disinfectants
}

\author{
Anyim Chukwudi ${ }^{1}$, Ilang Donatus $C^{2}$, Okonkwo Eucharia C. ${ }^{1}$ \\ ${ }^{1}$ Department of Applied Microbiology, Faculty of Biological Sicences, Ebonyi State University, Abakaliki, Nigeria \\ ${ }^{2}$ Department of Biological Sciences, Faculty of Science and Technology, Federal University Ndufu Alike-Ikwo, Ebonyi State, Nigeria
}

\section{Email address:}

anyim5live@gmail.com(A. Chukwudi)

\section{To cite this article:}

Anyim Chukwudi, Ilang Donatus C, Okonkwo Eucharia C.. Bacteriological Examination of Computer Keyboards and Mouse Devices and their Susceptibility Patterns to Disinfectants. American Journal of Bioscience and Bioengineering. Vol. 1, No. 3, 2013 , pp. $36-43$. doi: 10.11648/j.bio.20130103.11

\begin{abstract}
Computers are ubiquitous and have been shown to be contaminated with potentially pathogenic bacteria in some communities. There is no economical way to test all the keyboards and mouse out there, but there are common-sense ways to prevent bacterial contamination or eliminate it if it exists. In this study, swabs specimens were collected from surfaces of 250 computer keyboards and mouse and plated on different bacteriological media. Organisms growing on the media were purified and identified using microbiological standards. It was found that all the tested computer keyboards and mouse devices, were positive for microbial contamination. The percentages of isolated bacteria (Staphylococcus spp., Escherichia spp., Pseudomonas spp. and Bacillus spp.) were 43.3\%, 40.9\%, 30.7\%, 34.1\%, 18.3\%, 18.2\%, 7.7\% and 6.8\% for computer keyboards and mouse respectively. The isolated bacteria were tested against the 6 different disinfectants (Dettol, Isol, Izal, JIK, Purit and Septol ${ }^{\circledR}$ ). Antibacterial effects of the disinfectants were also concentration dependent. The agar well diffusion technique for determining Minimum Inhibitory Concentration (MIC) was employed. The Killing rate (K) and Decimal Reduction Time (DRT) of the disinfectants on the organism were also determined. The overall result of this study showed that Dettol ${ }^{\circledR}$, followed by JIK ${ }^{\circledR}$ was highly effective against all the bacterial isolates tested while Septol and Izal ${ }^{\circledR}$ were least effective. Isol and Purit ${ }^{\circledR}$ showed moderate antibacterial effects. Keyboards and mouse should be disinfected daily. However, it is recommended that heightened surveillance of the microbial examination of computer keyboards should be undertaken at predetermiant intervals.
\end{abstract}

Keywords: Bacteria, Disinfectants, Antibacterial Activity, MIC, DRT, Killing Rate

\section{Introduction}

Computer is an electronic data processing machine which accepts data from the out-side world inform of an input and manipulates, calculates, computes on the basis of set of instructions supplied and stored in the memory and give the required or desired results in the form of an output to the user (1). Because of frequent-dermal contact by numerous users, microbial reservoirs of interest includes the computer keyboard and mouse (2-3). Anderson and Palambo (4) documented that the average number of microorganisms present on multiple-user computer keyboards was significantly greater than on single-user keyboards.

Computer hardware has been implicated as a potential reservoir for infectious agents (5). Of increasing concern, however, is the role of keyboards in the non-hospital environment as pathogen reservoirs (6). It follows that the ubiquitous sharing of public computers by a broad user base might facilitate increased transmission and prevalence of pathogenic microorganisms throughout the community (7). Inadequately performed hand hygiene and nondisinfected surfaces are two reasons why the keys and mouse-buttons of laptops could be sources of microbial contamination resulting consequently in indirect transmission of potential pathogens and nosocomial infections (8).

Surprisingly, little effort has been dedicated to identify the role of inanimate surfaces as pathogen reservoirs in the non-hospital settings (9-10). Therefore, successive steps to edge the spread of antimicrobial resistant pathogens 
throughout the community should include efforts to not only increase awareness of appropriate hygiene and decontamination strategies, but also to reveal the ecology of bacteria contaminating community surfaces.

This study was undertaken to evaluate the bacteriological examination of computer keyboards and mouse devices and their susceptibility patterns to commonly used disinfectants.

\section{Materials and Methods}

\subsection{Study Area}

This study was conducted within three campuses (Presco, CAS and Ishieke) of the Ebonyi State University, Abakaliki.

\subsection{Ethical Clearance}

The consent and permission of the cyber cafes owners were inquired in order to carry out this research work. Subsequently, the confidentiality of the information obtained from cyber cafes was kept.

\subsection{Sample Collection and Preparation}

The surfaces of 250 computer keyboards and mouse of 15 cyber cafes in three campuses (Presco, CAS and Ishieke) were randomly selected for this study. This was performed during operating hours featuring normal students and staff traffic at the cyber cafes. The single sterile swab stick moistened with sterile saline solution were moved over the surfaces being tested (keyboard and mouse). The swab sticks were immediately transported to the laboratory.

\subsection{Collection of Disinfectants}

The following disinfectants: Dettol ${ }^{\circledR}$ (Reckitt Benkiser Ltd, Nigeria), Isol ${ }^{\circledR}$ (Medreich Ltd, Nigeria), Izal ${ }^{\circledR}$ (Medreich Ltd, Nigeria), JIK ${ }^{\circledR}$ (Reckitt Benkiser Ltd, Nigeria), Purit ${ }^{\circledR}$ (Saro Lifecare Ltd, Nigeria) and Septol ${ }^{\circledR}$ (Gongoni Company Ltd, Nigeria) commonly used in Abakaliki Metropolis were obtained from Ceno Pharmacy, Abakaliki, Ebonyi State.
Identification of the test isolates was done based on morphological and biochemical test: Sugar fermentation test (glucose, fructose and lactose), Voges Proskauer test, catalase test, coagulase test, oxidase test and indole test, including Gram staining reaction and motility test was carried out for proper characterization of bacterial isolates according to Cheesbrough (11).

\subsection{Dilution of Disinfectant}

Serial dilution method was used to dilute the disinfectants into 50, 25 and $12.5 \%$ concentration according to Awodele et al. (2007).

\subsection{Standardization of Test Organisms}

The isolates used for sensitivity were standardized using the 0.5 McFarland equivalent standard as described by Cheesbrough (2006).

\subsection{Susceptibility Testing}

The susceptibility testing of the commonly used disinfectants were ascertained using agar well diffusion method (12-13).

\section{Results}

The organisms were then characterized as shown in Table 1. Four bacteria were isolated in this study and suspected to contaminate computer keyboards and mouse.

Out of 250 samples analyzed, a total of 148 bacteria isolates were isolated from computer keyboards and mouse. Out of which 63 Staphylococcus spp. were present; 45 of the isolates were from keyboards and 18 from mouse. 11 were Bacillus spp.; 8 of the isolates from keyboards and 3 from mouse. 47 were Escherichia spp.; 32 of the isolates from keyboards and 15 from mouse. 27 were Pseudomonas spp.; 19 of the isolates from keyboards and 8 from mouse. A total of 104 bacterial isolates were obtained from keyboards and 44 bacterial isolates from mouse (Table 2).

\subsection{Identification of the Isolates}

Table 1. Morphological and biochemical test result of bacterial isolated from computer keyboards and mouse

\begin{tabular}{|c|c|c|c|c|c|c|c|c|c|c|c|}
\hline \multicolumn{5}{|c|}{ Morphological characterization } & \multicolumn{7}{|c|}{ Sugar fermentation test } \\
\hline Consistency/ & Gram & Catalase & Oxidase & Indole & Voges & Motility & & & & Suspected & \\
\hline Creamy & $\begin{array}{l}\text { Raised/smooth } \\
\text { edge }\end{array}$ & $+\mathrm{ve}$ & + & - & - & - & - & + & - & - & $\begin{array}{l}\text { Staphylococcus } \\
\text { spp. }\end{array}$ \\
\hline Grayish & $\begin{array}{l}\text { Small round } \\
\text { colony }\end{array}$ & + ve & - & + & - & - & - & + & - & - & Bacillus spp. \\
\hline Greenish & Rough surface & -ve & + & - & + & - & - & + & + & - & $\begin{array}{l}\text { Escherichia } \\
\text { spp. }\end{array}$ \\
\hline Light yellow & Slightly raised & $-\mathrm{ve}$ & + & + & - & - & - & + & - & - & $\begin{array}{l}\text { Pseudomonas } \\
\text { spp. }\end{array}$ \\
\hline
\end{tabular}


Table 2. Frequency of bacterial occurrence in computer keyboards and mouse

\begin{tabular}{cccc}
\hline Isolates (\%) & Keyboards (\%) & Mouse (\%) & Total No. \\
\hline Staphylococcus spp. & $45(43.3)$ & $18(40.9)$ & $63(42.6)$ \\
Bacillus spp. & $8(7.7)$ & $3(6.8)$ & $11(7.4)$ \\
Escherichia spp. & $32(30.7)$ & $15(34.1)$ & $47(31.8)$ \\
Pseudomonas spp. & $19(18.3)$ & $8(18.2)$ & $27(18.2)$ \\
Total & 104 & 44 & 148 \\
\hline
\end{tabular}

Table 3. Antimicrobial activities of disinfectants against organisms at 100, 50, 25 and 12.5\% concentration and inhibition zone diameter (mm)

\begin{tabular}{|c|c|c|c|c|c|c|c|c|c|c|c|c|c|c|c|c|}
\hline \multirow[b]{2}{*}{ Disinfectants } & \multicolumn{4}{|c|}{ Staphylococcus spp. } & \multicolumn{4}{|c|}{ Bacillus spp. } & \multicolumn{4}{|c|}{ Escherichia spp. } & \multicolumn{4}{|c|}{ Pseudomonas spp. } \\
\hline & 100 & $\mathbf{5 0}$ & 25 & 12.5 & 100 & 50 & 25 & 12.5 & 100 & 50 & 25 & 12.5 & 100 & 50 & 25 & 12.5 \\
\hline Dettol $^{\circledR}$ & 15 & 12 & 10 & 10 & 14 & 10 & 14 & 8 & 15 & 13 & 10 & 12 & 14 & 10 & 12 & 8 \\
\hline Isol $^{\circledR}$ & 12 & 10 & 7 & 4 & 10 & 11 & 5 & - & 11 & 8 & - & - & 10 & 8 & 5 & - \\
\hline $\mathrm{Izal}^{\circledR}$ & 8 & - & - & - & 12 & 4 & - & - & 10 & 5 & - & - & 5 & - & - & - \\
\hline $\mathrm{JIK}^{\circledR}$ & 13 & 12 & 10 & 8 & 13 & 12 & 11 & 5 & 12 & 5 & 8 & 5 & 10 & 11 & 9 & 7 \\
\hline Purit $^{\circledR}$ & 10 & 8 & 5 & - & 9 & - & 5 & - & 5 & - & 4 & - & 7 & 4 & - & - \\
\hline Septol $^{\circledR}$ & 5 & - & - & - & 9 & 6 & - & - & - & - & - & - & 10 & 5 & - & - \\
\hline
\end{tabular}

Table 4. Minimum inhibitory concentration of disinfectants against test bacteria

\begin{tabular}{ccccccc}
\hline Strain Name & $\begin{array}{c}\text { MIC (mL/mL) } \\
\text { Dettol }\end{array}$ & & & & & \\
Isol $^{\circledR}$ & Izal $^{\circledR}$ & JIK $^{\circledR}$ & Purit $^{\circledR}$ & Septol $^{\circledR}$ \\
\hline $\begin{array}{c}\text { Staphylococcus } \\
\text { spp. }\end{array}$ & 4.5731 & 3.5375 & 4.9556 & 3.4498 & 1.0273 & 3.5156 \\
Bacillus spp. & 1.5093 & 2.1468 & 1.9063 & 3.7273 & 1.9629 & 2.5182 \\
\hline
\end{tabular}

At $100 \%$ concentration, Dettol ${ }^{\circledR}$ and $\mathrm{JIK}^{\circledR}$ were the most effective in inhibiting the four organism tested, followed by Isol $^{\circledR}$, while Septol ${ }^{\circledR}$, showed the lowest inhibitory activity on all the organisms at $100 \%$ concentration (Table 3 ).

However, at $50 \%$ concentration Dettol and $\mathrm{JIK}^{\circledR}$ were also the most effective in inhibitory activities, followed by Isol ${ }^{\circledR}$ on the four organism tested. Izal ${ }^{\circledR}$ showed no inhibitory activity on Staphylococcus and Pseudomonas spp., but showed inhibitory activities on Bacillus and Escherichia spp. In the same vein, Purit ${ }^{\mathbb{R}}$ showed inhibitory activities on Staphylococcus and Pseudomonas spp., but had no inhibitory effect on Bacillus and Escherichia spp. At this 50\% concentration, Septol $^{\circledR}$ showed inhibitory activities on Bacillus spp. and Pseudomonas spp., but disclosed no inhibitory effect on Staphylococcus and Escherichia spp.

Furthermore, at $25 \%$ concentration it was revealed that Dettol and JIK ${ }^{\circledR}$ showed reasonable inhibitory activities on Staphylococcus, Bacillus, Escherichia and Pseudomonas spp. followed by Isol $^{\circledR}$ on Staphylococcus, Bacillus and Pseudomonas spp. respectively and showed no inhibitory activity on Escherichia species. Purit ${ }^{\circledR}$ showed inhibitory activities on Staphylococcus, Bacillus and Escherichia spp., but had no inhibitory activity on Pseudomonas spp. Izal and Septol ${ }^{\circledR}$ did not show any inhibitory activity at this $25 \%$ concentration to the entire organisms tested.

Finally, at $12.5 \%$ concentration, Dettol and $\mathrm{JIK}^{\circledR}$ demonstrated inhibitory activities on Staphylococcus, Bacillus, Escherichia and Pseudomonas spp. Isol ${ }^{\circledR}$ showed inhibitory activity on only Staphylococcus spp. and had no inhibitory effect on the other organisms. At same $25 \%$ concentration, Purit, Izal and Septol ${ }^{\mathbb{B}}$ revealed no inhibitory effects on the other organisms tested.

The killing rates $(\mathrm{K})$ of the organisms obtained from the graphs are given in Table 5. The higher the value of $k$, the faster the efficiency of the killing process. The killing rates of Staphylococcus spp. by Dettol ${ }^{\circledR}$ were higher than for other disinfectants. Thus, the killing rates $(\mathrm{K})$ of Staphylococcus spp. were -0.044, -0.048, -0.052, -0.058, 0.086 and -0.058 for Dettol, JIK, Isol, Purit, Izal and Septol ${ }^{\circledR}$ respectively. The killing rates $(\mathrm{K})$ of Bacillus spp. were $-0.046,-0.050,-0.055,-0.050,-0.061$ and 0.055 in Dettol, JIK, Isol, Purit, Izal and Septol ${ }^{\circledR}$ respectively. The killing rates of the other 2 organisms (Escherichia spp. and Pseudomonas spp.) followed a similar pattern.

Table 6 and 7 showed the slopes and the Decimal Reduction Times (DRT) respectively. The DRT is known to be the time required for $90 \%$ reduction in the number of viable cells (Meynell and Meynell, 1970). The DRT for Staphylococcus spp. were 30.30, 33.33, 35.71, 40.00, 58.82 and $40.00 \mathrm{~min}$ in Dettol, JIK, Isol, Purit, Izal and Septol ${ }^{\circledR}$ respectively, while for Bacillus spp. were 32.29, 34.48, 38.46, 34.48, 41.67 and $25.64 \mathrm{~min}$ in Dettol, JIK, Isol, Purit, Izal and Septol ${ }^{\circledR}$ respectively. A similar pattern was recorded for the other 2 organisms (Escherichia spp. and Pseudomonas spp.).

The higher the value of killing rate $(\mathrm{K})$, the lower the value of Decimal Reduction Time (DRT).

Colony counting technique was used to determine the number of colony that survived the effects of various dilutions of each disinfectants and the data plotted as $\log _{10}{ }_{\mathrm{t}}^{\mathrm{N}}{ }_{\mathrm{o}}$ versus time as in Fig. 1 (Staphylococcus spp.), Fig 2 (Bacillus species), Fig. 3 (Escherichia spp.) and Fig. 4 (Pseudomonas spp.). For all the organisms there was an overall similarity in the shapes of the curves. The curves initially showed a lag, the duration of which depended on the concentration of the disinfectant and the type of organism. 


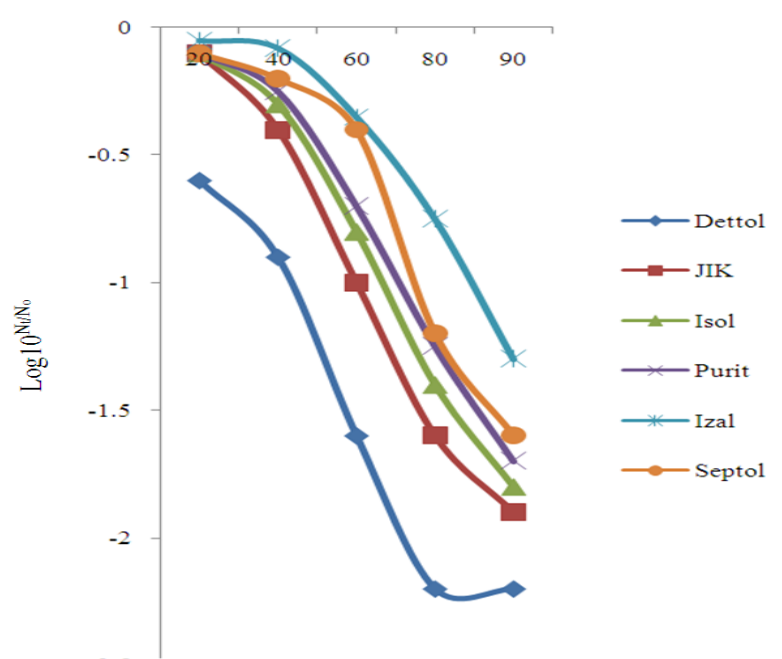

Fig. 1. Survivor curve of the effect of the various disinfectants on Staphylococcus spp.

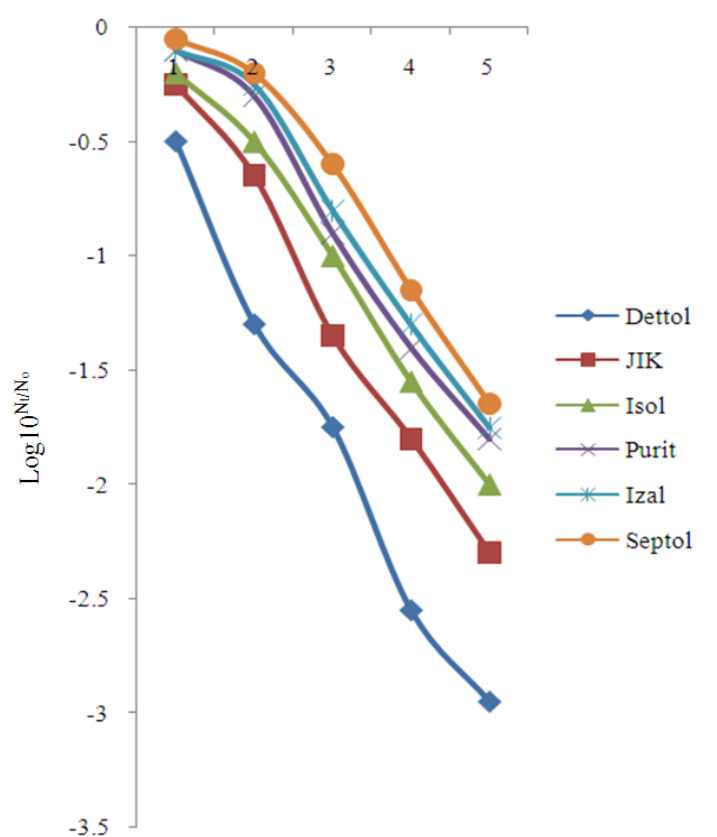

Fig. 2. Survivor curve of the effect of the various disinfectants on Bacillus spp

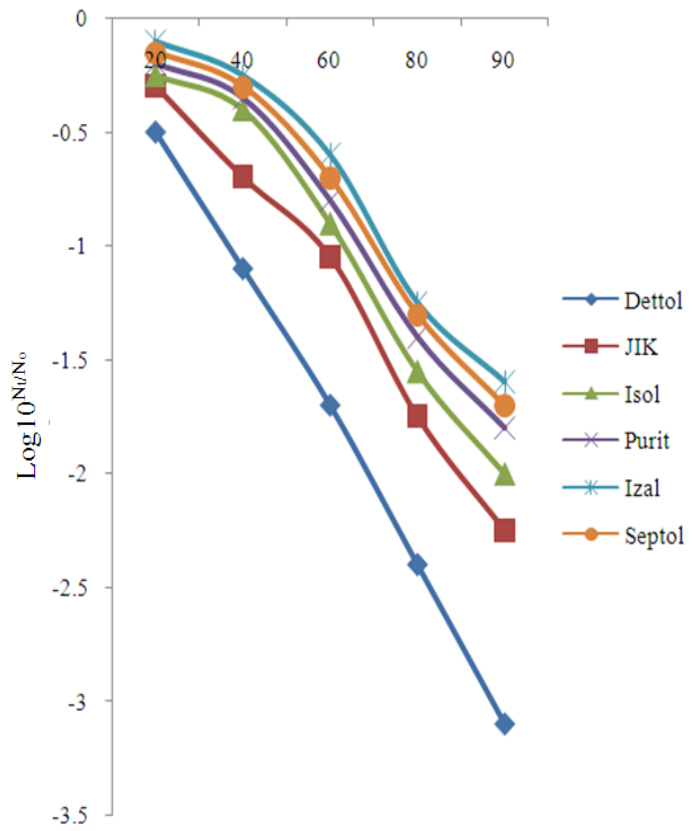

Fig. 3. Survivor curve of the effect of the various disinfectants on Escherichia spp

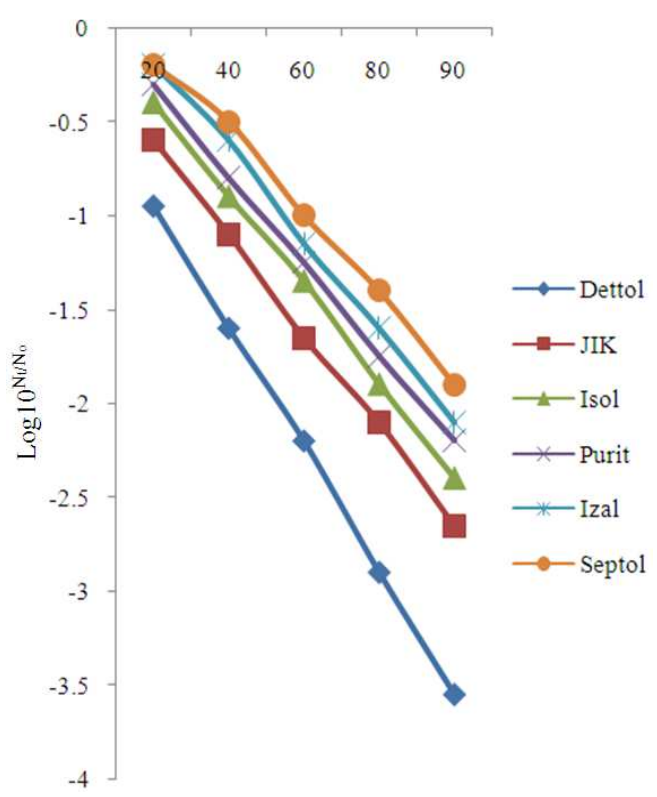

Fig. 4. Survivor curve of the effect of the various disinfectants on Pseudomonas spp

Table 5. Killing rate $(K)$ of the organisms treated with the various disinfectants

\begin{tabular}{ccccccc}
\hline Staphylococcus spp & $\mathbf{- 0 . 0 4 4}$ & $\mathbf{- 0 . 0 4 8}$ & $\mathbf{- 0 . 0 5 2}$ & $\mathbf{- 0 . 0 5 8}$ & $\mathbf{- 0 . 0 8 6}$ & $-\mathbf{0 . 0 5 8}$ \\
\hline Bacillus spp & -0.046 & -0.050 & -0.055 & -0.050 & -0.061 & -0.055 \\
Escherichia $\mathrm{spp}$ & -0.044 & -0.055 & -0.055 & -0.055 & -0.058 & -0.058 \\
Pseudomonas $\mathrm{spp}$ & -0.044 & -0.058 & -0.050 & -0.061 & -0.055 & -0.058 \\
\hline
\end{tabular}

Table 6. Slope (S) of the survivor curves of the organisms treated with the various disinfectants

\begin{tabular}{ccccccc}
\hline Strain Name & Dettol $^{\circledR}$ & Isol $^{\circledR}$ & Izal $^{\circledR}$ & JIK $^{\circledR}$ & Purit $^{\circledR}$ & Septol $^{\circledR}$ \\
\hline Bacillus spp & -0.033 & -0.030 & -0.028 & -0.025 & -0.017 & -0.025 \\
Staphylococcus spp. & -0.031 & -0.029 & -0.026 & -0.029 & -0.024 & -0.039 \\
Escherichia spp. & -0.033 & -0.026 & -0.039 & -0.026 & -0.025 & -0.025 \\
spp. & -0.033 & -0.025 & -0.026 & -0.024 & -0.026 & -0.025 \\
\hline
\end{tabular}


Devices and their Susceptibility Patterns to Disinfectants

Table 7. Decimal reduction time (min) of the organisms treated with the various disinfectants

\begin{tabular}{ccccccc}
\hline Strain Name & Dettol $^{\circledR}$ & Isol $^{\circledR}$ & Izal $^{\circledR}$ & JIK $^{\circledR}$ & Purit $^{\circledR}$ & Septol $^{\circledR}$ \\
\hline $\begin{array}{c}\text { Staphylococcus } \\
\text { spp. }\end{array}$ & 30.30 & 33.33 & 35.71 & 40.00 & 58.82 & 40.00 \\
$\begin{array}{c}\text { Bacillus spp. } \\
\text { Escherichia spp. }\end{array}$ & 32.29 & 34.48 & 38.46 & 34.48 & 41.67 & 25.64 \\
$\begin{array}{c}\text { Pseudomonas } \\
\text { spp. }\end{array}$ & 30.30 & 38.46 & 25.64 & 38.46 & 40.00 & 40.00 \\
\hline
\end{tabular}

\section{Discussion}

Numerous studies have indicated that computer keyboards (and mouse) can become contaminated with pathogenic bacteria $(7,14-19)$. In health care settings, it is perhaps not unexpected that such microorganisms would contaminate these common work surfaces. However, this present work showed that microbial contamination also occurs on computer keyboards and mouse located in a large university environment.

A total of 250 computer keyboards and mouse were examined for bacterial contamination. The bacteria isolated (Staphylococcus, Bacillus, Escherichia and Pseudomonas spp.) and their percentages of occurrence were represented in Table 1 and 2 respectively. The contamination rate of keyboards and mouse was $70.3 \%$ and $29.7 \%$, respectively. It was revealed by Hartmann et al. (15) that the highest rate of contamination in patients, rooms was found on keyboards. Schultz et al. (14) found that the tested 100 keyboards in 29 clinical areas for bacterial contamination, 95 from them were positive for microbial contamination. Eltablawy and Elhifnawi (7) also showed that all the tested 24 computer keyboards and mouse at National Center for Radiation Research and Technology (NCRRT), were positive for microbial contamination. However, the degree of microbial contamination of computer keyboards and mouse is high enough to potentially allow transmission via contaminated hands (16).

Out of 250 samples analyzed, a total of 148 bacteria isolates were obtained from computer keyboards and mouse. Out of these, $42.6 \%$ are Staphylococcus spp., $31.8 \%$ are Escherichia spp., 18.2\% are Pseudomonas spp.and 7.4\% are Bacillus spp.. This is in line with the study of Rutala et al. (16) who reported that potential pathogens cultured from more than $50 \%$ of the computers included coagulasenegative Staphylococci (100\% of keyboards), diphtheroids (80\%), Micrococcus spp. (72\%) and Bacillus spp. (64\%).

Anastasiades et al. (17) reported the presence of coagulase-negative staphylococci (68.5\%), Staphylococcus aureus (2.1\%), Gram-positive bacilli (27.1\%), Micrococcus $(0.6 \%)$ and fungi (1.7\%) on computer keyboards and mouse, indicating that Staphylococcus spp. are prevalent on computer keyboards and mouse compared to other microbial communities. The ecologic niche for $S$. aureus in humans is in the anterior nares (20). One-quarter to one-third of healthy persons harbour $S$. aureus in the nose at any time
(21) which can easily be transferred to hands by simply rubbing the nose. In this present work the highest bacterial population on computer keyboards and mouse were $S$. aureus $(42.6 \%)$. This strengthens the possibility of transfer of potentially pathogenic $S$. aureus through human hands which could include antibiotic resistant bacteria such as community associated Methicillin-Resistant S. Aureus (MRSA) (20). Inanimate objects have been known to play a role in the transmission of human pathogens either directly by surface to mouth contact or indirectly by contamination of fingers and subsequent hand to mouth contact (22). In addition, one's palm is usually moist to a varying degree due to perspiration, which contains sodium chloride that will sustain the growth of halophilic bacteria such as S. aureus (23-24).

Shen (18) who investigated the bacterial contamination of computer keyboards and mouse in the office reported the presence of Staphylococcus aureus, Escherichia coli and Salmonella spp. before sterilization at the following frequency 50.0, 41.7 and 8.3\%. Many other investigators found the presence of Escherichia spp. on computer keyboards and mouse $(2,16,25-27)$. This signifies that Escherichia spp. can also be isolated from computer keyboards and mouse at a relatively high proportion, which is in line with the result of this present work, Escherichia spp. $(31.8 \%)$.

Noskin et al. (28) studied both computer keyboards and keyboard covers, reported their ability to harbour Vancomycin-Resistant Enterococcus faecium (VRE), Methicillin-Resistant Staphylococcus Aureus (MRSA) and Pseudomonas aeruginosa. Also Tagoe and Kumi-Ansah (19) who investigated the bacterial contaminants of keyboards and mice in general offices and internet cafés, reported the presence of Pseudomonas aeruginosa. The presence of Pseudomonas aeruginosa shown by Noskin et al. (28) and Tagoe and Kumi-Ansah (19) is consistent with this study, showing that Pseudomonas spp. can be isolated from computer keyboards and mouse. Hence Infectious doses of this pathogen may be transferred to the mouth after handling an everyday contaminated object.

Eltablawy and Elhifnawi (7) reported the presence of Bacillus cereus, Pseudomonas putida and Escherichia tarda, which are known to be pathogenic in nature. Das et al. (29) reported that computer Keyboards and mouse harbour many pathogenic microorganisms, of which Bacillus species were shown to be the most predominant. Contrarily, Bacillus spp. was isolated in this study at the lowest proportion (7.4\%), but also a clear indication that computer keyboards and mouse are 
polymicrobial in nature. The isolation of Bacillus spp., common soil bacteria, is evidence of environmental contamination (4).

The results obtained in this study showed that the antibacterial activities of the tested disinfectants were concentration dependent. Table 3 showed that Dettol and $\mathrm{JIK}^{\circledR}$ was the most effective in inhibiting the four bacteria at $100 \%$ concentration, followed by Isol, Izal and Purit ${ }^{\circledR}$, while Savlon ${ }^{\circledR}$ showed inhibitory activity on Staphylococcus, Bacillus and Pseudomonas spp. only, but with lower zones of inhibition than Dettol and $\mathrm{JIK}^{\circledR}$ on all the organisms tested, also Septol ${ }^{\circledR}$ showed lower zones of inhibition than Isol, Izal and Purit ${ }^{\circledR}$ on Staphylococcus and Escherichia spp.

However, at $50 \%$ concentration Dettol and $\mathrm{JIK}^{\circledR}$ were also the most effective in inhibitory activities: 12, 10, 13, 10, 13, 12, 5 and 14mm on Staphylococcus, Bacillus, Escherichia and Pseudomonas spp. respectively. This was followed by Isol ${ }^{\circledR}$ with inhibition zones of $10,11,8$ and 8 $\mathrm{mm}$ ) on the four organism tested. Izal ${ }^{\circledR}$ showed no inhibitory activity on Staphylococcus and Pseudomonas spp., but showed inhibitory activities on Bacillus and Escherichia spp. with inhibition zones of 4 and $5 \mathrm{~mm}$ respectively. In the same vein, Purit ${ }^{\circledR}$ showed inhibitory activities on Staphylococcus and Pseudomonas spp. with inhibition zones of $8 \mathrm{~mm}$ and $4 \mathrm{~mm}$ respectively, but has no inhibitory effect on Bacillus and Escherichia spp. At this $50 \%$ concentration Septol ${ }^{\circledR}$ inhibitory activities on Bacillus and Pseudomonas spp. with inhibition zones 6 and $5 \mathrm{~mm}$ respectively, but disclose no inhibitory effect on Staphylococcus and Escherichia spp. Olowe et al. (30) reported that Dettol and Savlon ${ }^{\circledR}$ were effective against many pathogenic organisms, especially when the number of cells present were not disinfected in the presence of excess organic matter. Hence this calls for the need for the proper removal of crumbs and spills which wind up on and between the keys that are likely to encourage the growth of microorganisms, before the commencement of disinfection practice.

However, at $12.5 \%$ concentration, Dettol and $\mathrm{JIK}^{\circledR}$ demonstrated the following zones of inhibition; 10, 8, 12, 8, 8, 5, 5 and $8 \mathrm{~mm}$ on Staphylococcus, Bacillus, Escherichia and Pseudomonas spp. respectively. Isol $^{\circledR}$ showed inhibitory activity on only Staphylococcus spp. with inhibition zone of $4 \mathrm{~mm}$ and has no inhibitory effect on the other organisms. At same $25 \%$ concentration Purit, Izal and Septol $^{\circledR}$ revealed no inhibitory effects on the other organisms tested. The low inhibitory activities of Septol ${ }^{\circledR}$ on the various organisms isolated might be attributed to active ingredients contained in Septol ${ }^{\circledR}$. The resistance of microorganisms is known to be limited to only a few antimicrobial agents (30). Some disinfectants are reported to share the same mechanism of action with some antibiotics and this can cause resistance to disinfectants used in cleaning our environments (31). Some other studies have also suggested a potential molecular link between reduced susceptibility to some disinfectants and antibiotic resistance (32). In the same vein, Iroha et al. (13) reported that resistance of microorganisms to disinfectants within the hospital, industry and other community setting is an emerging public health concern.

The mechanism of action of disinfectant or antiseptic on the micro-organism remains the same irrespective of the type and is exerted through the penetration into the cell and action at the target site(s). The latter can produce a significant effect on the viability as most of the biocides appear to act through intra-cellular mechanism (33). The sensitivity or resistance at the level of the bacterial cell membrane, therefore, can be very important factor in determining the final outcome of the treatment with the proposed disinfectant in the hospital practice. Some of these disinfectants also work by production of destructive chemicals against various pathogenic bacteria to attack membrane lipids, DNA and other essential cell components (34).

Most antimicrobial agents show both inhibitory and lethal effects depending on the concentration used and other factors such as degree of contamination and duration of treatment. The MIC is a helpful parameter used to assess the bacteriostatic activity of a given disinfectant (30). The MIC values of dettol, jik, isol, purit, septol and izal obtained in this study showed that concentration of the active ingredients in the recommended dilutions of the disinfectants is lethal to the organisms tested. The relationship between the MIC and the content of the disinfectant is considered to be a useful property of the agents (35). Subsequently, the MIC recorded in this study further indicated that the test organisms screened were most resistant to Septol, followed by Izal and Purit ${ }^{\circledR}$ (Table 4). The high rate of decreased susceptibility to these disinfectants (Septol, Izal and Purit ${ }^{\circledR}$ ) is worrisome considering the fact that they are among the disinfectants commonly used in our environment.

Counting methods have been used to determine the number of microbial cells that survived the toxic effects of disinfectant at various time intervals for a particular period. The antimicrobial activity of the various disinfectants was assessed by performing viable cell counts at 20,40,60, 80 and $90 \mathrm{~min}$. The number of cells in organisms was observed to decrease gradually after an initial lag, the duration of which is a function of the concentration of the various disinfectants used and the type of organisms. The number of cells decreased faster in Dettol ${ }^{\circledR}$, followed by $\mathrm{JIK}^{\circledR}$ than in Isol, Purit, Izal and Septol ${ }^{\circledR}$ with negative slopes. When a microbial population is subjected to the toxic influence of an agent, the number of cells decreased gradually in such a manner that when the logarithm of the number of cell at any time when plotted against that time falls on a descending straight line with a negative slope (36). This is referred to as the logarithmic order of death (37) as shown in Table 5. On the other hand, a nonlogarithmic order of death had also been reported (38-39). 
One characteristic of the logarithmic order of death is that there is a linear relationship between the logarithm of the number of survivors and time. This means that at any time interval a constant proportion of cells loose viability. All the organisms exhibited a uniform response to the various disinfectants as shown by the almost straight graphs (Fig. 14). This is an indication that there is no sub population of cells resistant to the various disinfectants in the test cultures. Extensive work on the mechanism of death in the presence of microbicidal concentrations of phenols and halogenated phenols (including dichloroxylenol and chlorophenol) had been documented and the mode of action of these compounds had been found to be due to their adverse effect on cellular permeability leading to inhibition of enzymes and leakage of intracellular materials out of the cell (4041). Thus, the cytoplasmic membrane and its component are considered to be the main site of action of the disinfectants used in the presence of lag especially in the higher usedilutions of this study. The lag is more pronounced when Dettol ${ }^{\circledR}$ was used than other disinfectants in this study. The presence of the lag in microbicidal concentrations of toxic agents have been attributed to non uniform distribution of the cells in the suspension as single cells, but were rather grouped as clumps ( 42-43).

However, results of this study revealed low values of the lag where high concentration of Dettol and JIK $^{\circledR}$ used the treatment of the organisms. Variations in use dilutions of the disinfectants affected the kinetics of cell death with respect to the length of the lag, the DRT (Table 7) and the slope of the graphs (6). The relationship between the concentration of the various disinfectants used and the above parameters are measures of resistance of cells to the disinfectants. For complete killing of the cells, a sufficiently high concentration of a disinfectant molecule must be in contact with the organisms for a time greater than the lag prior to exponential order of death (43).

The Decimal Reduction Time (DRT), is the time required for a disinfectant at a certain temperature or concentration to kill $90 \%$ of the organisms being studied (44). The DRT was calculated from slopes of the curves (Table 7). The DRT depended on the concentration of the disinfectant and also on the type and resistance of the microorganism used. Thus in this study, the test organisms were more resistant to the activity of Septol and Izal ${ }^{\circledR}$ than Dettol, JIK, Isol and Purit $^{\circledR}$. The order of the decreasing activities of the disinfectants on the test organisms:Dettol $>$ JIK $>$ Isol $>$ Purit $>$ Izal $>$ Septol ${ }^{\circledR}$.

In this study, it was found that there was a higher contamination rate of computer keyboards and mouse. The use of Dettol ${ }^{\circledR}$ for the routine disinfection of computer keyboards and mouse is hereby highly suggested.

On the basis of these findings, it is suggested that routine cleaning of keyboards and mouse may aid the fight against pathogens in various communities. Also, hand washing before and after contact with keyboards and mouse should significantly reduce the risk of contamination and cross transmission.

\section{References}

[1] Ravichandran D. Introduction to computers and communication. Tata McGraw-Hill Publishing Company Limited, New Delhi, Inida, ISBN: 0-07-043565-0. 2006. P. 2.

[2] Neely AN, Holder IA, Wiener-Kromsh JP \& Sawa T. Passive anti-per $\mathrm{V}$ treatment protects burned mice against Pseudomonas aeruginosa challenge. Burns 2005, 31: 153158.

[3] Wilson AP, Hayman S, Folan P, Ostro PT \& Birkett A.. Computer keyboards and the spread of MRSA. J. Hosp. Infect 2006, 62: 390-402.

[4] Anderson G \& Palombo, EA. Microbial contamination of computer keyboards in a university setting. Am J Infect Control 2009, 37: 507-509.

[5] Neely AN, Weber JM, Daviau P, MacGregor A, Miranda C, Nell M, Bush P, Lighter D \& Shriners Hospitals for Children task force. Computer equipment used in patient care within a multihospital system: recommendations for cleaning and disinfection. Am J Infect Control 2005, 33(4): 233-237.

[6] Eguia JM \& Chambers HF. Community-acquired methicillin-resistant Staphylococcus aureus: Epidemiology and potential virulence factors. Curr Infect Dis Rep 2003, 5: 459-466.

[7] Eltablawy SY \& Elhifnawi HN. Microbial contamination of some computer keyboards and mice in National Centre for Radiation Research and Technology. World Appl Sci J 2009, 6(2):162-7.

[8] Siegmund K, Hübner, N, Heidecke CD, Brandenburg R \& Rackow, K. Are laptop ventilation-blowers a potential source of nosocomial infections for patients? GMS Krankenhaushyg Interdiszip 2010, 5: 7-7.

[9] Pancholi, P., M. Healy, T. Bittner, R. Webb and F. Wu et al., 2005. Molecular characterization of hand flora and environmental isolates in a community setting. J. Clin. Microbiol., 43: 5202-5207.

[10] Stepanović S, Cirković I, Djukić S, Vuković D. \& SvabićVlahović M. Public transport as a reservoir of methicillinresistant staphylococci. Lett Appl Microbiol 2008, 47: 339341.

[11] Cheesbrough M. District Laboratory Practice in Tropical Countries. 2nd Edn., Cambridge University Press, Cambridge, ISBN-10: 113944929X, 2006, pp: 440.

[12] Awodele O, Emeka PM, Agbamuche HC \& Akintonwa A. The antimicrobial activities of some commonly used disinfectants on Bacillus subtilis, Pseudomonas aeruginosa and Candida albicans. Afr J Biotech 2007, 6: 987-990.

[13] Iroha IR, Oji AE, Nwosu OK \& Amadi ES. Antimicrobial activity of Savlon $\AA$, Izal ${ }^{\circledR}$ and Z-germicide ${ }^{\circledR}$ against clinical isolates of Pseudomonas aeruginosa from hospital wards. Eur J Dent Med 2011, 3: 32-35.

[14] Schultz M, Gill J, Zubairi S, Huber R \& Gordin F. Bacterial contamination of computer keyboards in a teaching hospital. Infect Control Hosp Epidemiol 2003, 24: 302-313. 
[15] Hartmann B, Benson M, Junger A, Quinzio L \& Rohrig R, Computer keyboard and mouse as a reservoir of pathogens in an intensive care unit. J Clin Monit 2004, 18: 7-12.

[16] Rutala WA, White MS, Gergen MF \& Weber DJ. Bacterial contamination of keyboards: Efficacy and functional impact of disinfectants. Infect. Control Hosp Epidemiol 2006, 27: 372-377.

[17] Anastasiades P, Pratt TL, Rousseau LH, Steinberg WJ \& Joubert G. Staphylococcus aureus on computer mice and keyboards in intensive care units of the Universitas Academic Hospital, Bloemfontein and ICU staff's knowledge of its hazards and cleaning practices. South Afr J Epidemiol Infect 2009, 24: 22-26.

[18] Shen $X$. Investigation of the bacterial contamination of computer keyboard and mouse in the office. J. Environ. Occupat. Med 2010, LDYX201003017.htm

[19] Tagoe DNA \& Kumi-Ansah, F. Computer keyboard and mice: Potential sources of disease transmission and infections. Internet J. Public Health 2011, 10.5580/a19.

[20] Miller LG \& Diep BA. Colonization, fomites and virulence: Rethinking the pathogenesis of community-associated methicillin-resistant Staphylococcus aureus infection. Clin. Infect. Dis 2008, 465: 752-760.

[21] Kluytmans J, Van-Belkum A. \& Verbrugh H. Nasal carriage of Staphylococcus aureus: Epidemiology, underlying mechanisms and associated risks. Clin Microbiol Rev 1997, 10: 505-550.

[22] Rusin P, Maxwell S. \& Gerba, C.. Comparative surface-tohand and fingertip-to-mouth transfer efficiency of grampositive bacteria, gramnegative bacteria and phage. J Appl Microbiol 2002, 93: 585-592.

[23] Elliot, T., M. Hastings and U. Desselberger, 1997. Lecture Notes on Medical Microbiology. 3rd Edn., Wiley-Blackwell, ISBN-10: 0632024461, pp: 352.

[24] Mandal BK, Wilkins EGL, Dunbar EM \& Mayon-White R. Lecture Notes: Infectious Diseases. 6th Edn., Wiley, Oxford, ISBN-10: 1405108207, 2005, pp: 280.

[25] Man GS, Olapoju M \& and Chadwick MV. Bacterial contamination of ward-based computer terminals. J Hosp Infect 2002, 52: 314-318.

[26] Neely AN \& Sittig D.F. Basic microbiologic and infection control information to reduce the potential transmission of pathogens to patients via computer hardware. J Am Med Info Assoc 2002, 9: 500-508.

[27] Kumar A \& Srivastava M. Computer components in college and its surroundings encompass the pathogenic bacteria. J Applied Sci Environ Sanit 2012, 7: 43-47.

[28] Noskin GA, Stosor V, Bednarz P. \& Suriano T. Recovery of vancomycin-resistant Enterococci on fingertips and environmental surfaces. Infect Control Hosp Epidemiol 1995. 16: 577-581.

[29] Das A, Kansal R., Asthana AK, Pandey A \& Madan M. EFomites. Annals Biol Res 2011, 2: 111-115.
[30] Olowe OA, Olayemi AB, Eniola KIT \& Adeyeba AO. Anti bacterial activity of some selected disinfectants regularly used in hospitals. Afr J Clin Exp Microbiol 2004, 5: 126-130.

[31] Heath RJ, White SW \& Rock CO. Lipid biosynthesis as a target for antibacterial agents. Prog. Lipid. Res 2001, 40: 467-497.

[32] Kaulfers PM, Karch H \& Laufs R. Plasmid-mediated formaldehyde resistance in Serratia marcescens and Escherichia coli: Alterations in the cell surface. Zentralbl Bakteriol Mikrobiol Hyg A 1987, 226: 239-248.

[33] Russell AD \& Chopra I.. Understanding Antibacterial Action and Resistance. 2nd Edn., Ellis Horwood, Hemel Hempstead, ISBN-10: 0131248278, 1996, pp: 292.

[34] Rutala WA, White MS, Gergen MF \& Weberm DJ. Bacterial contamination of keyboards: Efficacy and functional impact of disinfectants. Infect Control Hosp Epidemiol 2006, 28: 372-377.

[35] El-Mahmood AM \& Doughari JH. Bacteriological examination of some diluted disinfectants routinely used in the Specialist Hospital Yola, Nigeria. Afr J Pharmacy Pharmacol 2009, 3: 185-1909.

[36] Acheampong YB, El-Mahmood A \& Olurinola PF. The antibacterial properties of the liquid antiseptic TCP. Ind J Pharm Sci 1988, 50: 183-186.

[37] Esselen WB \& Pflug IJ. Thermal resistance of putrefactive anaerobe no. 3679 spores in vegetables in the tempetature range of $250-290^{\circ} \mathrm{F}$. Food Tech 1956, 10: 557-560.

[38] Reed JM, Bohrer CW \& Cameron EJ Spore destruction rate studies on organisms of significance in the processing of canned foods. Food Res 1951, 16: 383-408.

[39] El-Bisi HM \& Ordal ZS. The effect of certain sporulation conditions on the death rates of Bacillus coagulans var thermocidurans. J Bacteriol 1955, 71: 1-7.

[40] Alwood MC \& Hugo WB. The Leakage of Cations and Amino Acids from Staphylococcus aureus exposed to moist heat, phenol and dinitrophenol. J Applied Microbiol 1971, 34: $368-375$.

[41] Hugo WA \& Bloomfield SF. Studies on the mode of action of phenolic antibacterial agent fenticlor against Staphylococcus aureus and Escherichia coli 1. Adsorption of fenticlor by the bacterial cell and its antibacterial activity. J Appl Bacteriol 1971, 34: 557-567.

[42] Meynell GG \& Meynell E. Theory and Practice in Experimental Bacteriology. 2nd Edn., CUP Archive, ISBN10: 052107682X, 1970, pp: 346.

[43] Cove JH \& Holland KT. The effect of benzoyl peroxide on cutaneous micro-organisms in vitro. J Appl Bacteriol 1983, 54: $379-382$.

[44] Mazzola PG, Penna TCV \& Martins AM. Determination of decimal reduction time (D-value) of chemical agents used in hospitals for disinfection purposes. BMC Infect Dis 2003, 3: 131-140. 